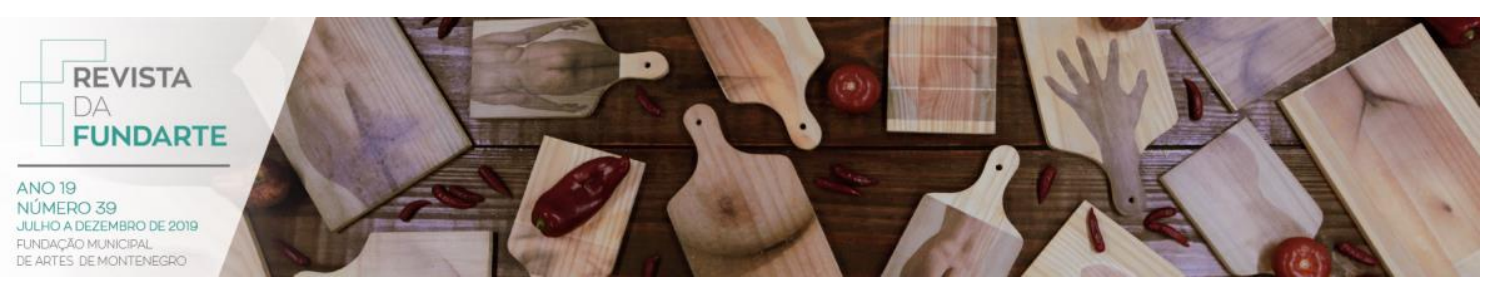

\title{
CINCO ESCRITOS PARA UM MOSAICO: PRODUÇÕES TEXTUAIS A PARTIR DE PESQUISAS ACADÊMICAS EM ARTES CÊNICAS
}

\author{
Vera Lúcia Bertoni dos Santos \\ Silvana Bággio Ávila \\ Débora Souto Allemand \\ Fellipe Santos Resende \\ lasmin D'Ornelas Ponsi \\ lassanã Martins
}

SANTOS, Vera Lúcia Bertoni (et.al). Cinco escritos para um mosaico: produções textuais a partir de pesquisas acadêmicas em artes cênicas. Revista da FUNDARTE, Montenegro, p.124-148, ano 19, nํ39, julho/dezembro de 2019.

Disponível em: http://.seer.fundarte.rs.gov.br/index.php/RevistadaFundarte/index> 20 de dezembro de 2019. 


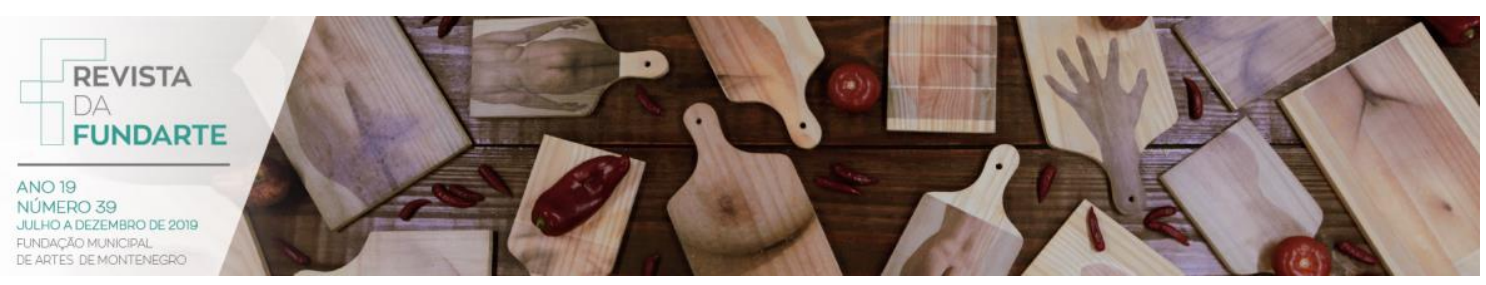

\title{
CINCO ESCRITOS PARA UM MOSAICO: PRODUÇÕES TEXTUAIS A PARTIR DE PESQUISAS ACADÊMICAS EM ARTES CÊNICAS
}

\author{
Vera Lúcia Bertoni dos Santos ${ }^{1}$ \\ Silvana Bággio Ávila² \\ Débora Souto Allemand ${ }^{3}$ \\ Fellipe Santos Resende 4 \\ lasmin D'Ornelas Ponsi ${ }^{5}$ \\ lassanã Martins ${ }^{6}$
}

\begin{abstract}
Resumo: $O$ trabalho resulta de uma atividade pedagógica realizada por um grupo de pesquisadores vinculados à disciplina de Seminário de Tese em Artes Cênicas, do currículo do Curso de Doutorado do Programa de Pós-Graduação em Artes Cênicas da UFRGS, oferecida em 2018. A experiência parte de uma proposta de análise, síntese e reflexão crítica de trabalhos acadêmicos representativos de conteúdos relacionados às pesquisas em andamento; e culmina na elaboração de produções textuais envolvendo temáticas emergentes no campo das Artes Cênicas. A apresentação do trabalho "em mosaico" reflete a diversidade de temáticas e a forma compartilhada de preparação dos escritos pelos sujeitos da experiência.
\end{abstract}

Palavras-chave: Pós-graduação; Experiência pedagógica; Universidade.

\section{FIVE WRITINGS FOR A MOSAIC: TEXTUAL PRODUCTIONS FROM ACADEMIC RESEARCHES IN PERFORMING ART}

\begin{abstract}
The article results from a pedagogical activity carried out by a group of researchers linked to the academic subject Seminário de Tese em Artes Cênicas, part of the PhD Course curriculum from the Postgraduate Program in Performing Arts, UFRGS, offered in 2018. The experience starts with a proposition of analysis, synthesis and critical reflection over academic papers representing content related to ongoing research; and culminates in the elaboration of textual productions involving emerging themes
\end{abstract}

\footnotetext{
1 Professora Associada vinculada ao Programa de Pós-Graduação em Artes Cênicas (PPGAC) e ao Departamento de Arte Dramática (DAD) do Instituto de Artes da Universidade Federal do Rio Grande do Sul (UFRGS); Doutora e Mestra em Educação pela UFRGS; Bacharela e Licenciada em Teatro pela UFRGS; Líder do Grupo de Estudos em Teatro e Educação (CNPq).

2 Doutoranda no PPGAC/UFRGS; Mestra em Artes Cênicas pela UFRGS; Bacharela em Interpretação Teatral pela Universidade Federal de Santa Maria (UFSM); Professora Adjunta do Departamento de Artes Cênicas da UFSM.

3 Doutoranda no PPGAC/UFRGS; Mestra em Arquitetura e Urbanismo pela Universidade Federal de Pelotas (UFPel); Bacharela em Arquitetura e Urbanismo e Urbanismo e Licenciada em Dança pela UFPel; Pesquisadora no Grupo de Pesquisa OMEGA (UFPel/CNPq); professora de dança

4 Doutorando no PPGAC/UFRGS; Mestre em Artes Cênicas pela UFRGS; Especialista em Dança pela UFRGS; Bacharel em Fisioterapia pela Universidade Federal de Goiás (UFG); instrutor do método Pilates e artista da Dança.

5 Doutoranda no PPGAC/UFRGS; Mestra em Estudos Teatrais pela Université Paris 8; Bacharela em Interpretação Teatral pela UFRGS; atriz, trapezista e professora.

${ }^{6}$ Doutoranda no PPGAC/UFRGS; Mestra em Artes Cênicas pela UFRGS; Licenciada em Teatro pela UFRGS; atriz e professora.
}

SANTOS, Vera Lúcia Bertoni (et.al). Cinco escritos para um mosaico: produções textuais a partir de pesquisas acadêmicas em artes cênicas. Revista da FUNDARTE, Montenegro, p.124-148, ano 19, nº 39, julho/dezembro de 2019.

Disponível em: http://.seer.fundarte.rs.gov.br/index.php/RevistadaFundarte/index> 20 de dezembro de 2019. 


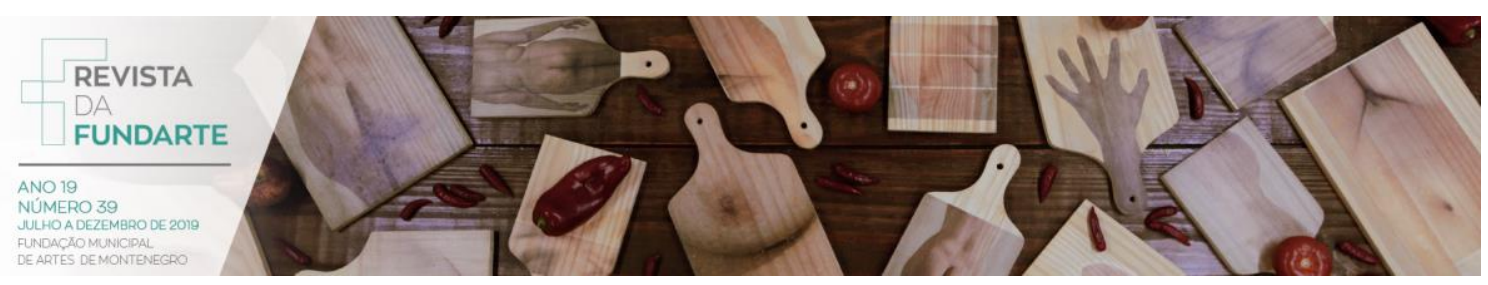

in the field of the Performing Arts. The presentation of the text "in mosaic" reflects the diversity of themes and the shared way of the writings preparation by the subjects of the experience.

Keywords: Postgraduate; Pedagogical experience; University.

\section{A PROPOSTA E SUAS INTENÇÕES, PROCEDIMENTOS E RESULTADOS ${ }^{7}$}

Este trabalho propõe-se a compartilhar resultados obtidos a partir de uma proposta curricular de qualificação acadêmica realizada no Programa de PósGraduação em Artes Cênicas (PPGAC) do Instituto de Artes da Universidade Federal do Rio Grande do Sul (UFRGS), na disciplina de Seminário de Tese em Artes Cênicas, no segundo semestre de 2018, por um grupo de seis pesquisadores: a professora da disciplina e cinco estudantes, vinculados ao Curso de Doutorado da Instituição.

O Seminário de Tese em Artes Cênicas destaca-se entre os componentes curriculares obrigatórios do Curso por propiciar aos estudantes de doutorado refletir sobre aspectos teóricos e metodológicos das suas pesquisas, de modo a identificar, formular e fundamentar conceitos operatórios ao desenvolvimento do trabalho investigativo, considerando seus referenciais de base e suas potencialidades de corresponder aos objetivos pretendidos.

O trabalho pedagógico inicia-se pela apresentação oral dos projetos de pesquisa dos doutorandos, o que possibilita uma visão geral das motivações e questões que orientam as investigações, bem como dos campos teóricos que as compreendem. No decorrer do processo realiza-se um seminário envolvendo discussões sobre alguns textos teóricos selecionados pela professora, de modo a contemplar concepções e metodologias de pesquisa em Artes Cênicas que oportunizem aos alunos divisar limites, potencialidades e especificidades das suas pesquisas, com vistas ao seu delineamento metodológico.

O processo de delimitação e ajuste de foco das pesquisas tende a potencializarse na medida do envolvimento entre os sujeitos da relação pedagógica com suas

${ }^{7}$ Escrito por Vera Lúcia Bertoni dos Santos.

SANTOS, Vera Lúcia Bertoni (et.al). Cinco escritos para um mosaico: produções textuais a partir de pesquisas acadêmicas em artes cênicas. Revista da FUNDARTE, Montenegro, p.124-148, ano 19, no 39, julho/dezembro de 2019.

Disponível em: http://.seer.fundarte.rs.gov.br/index.php/RevistadaFundarte/index $>20$ de dezembro de 2019. 


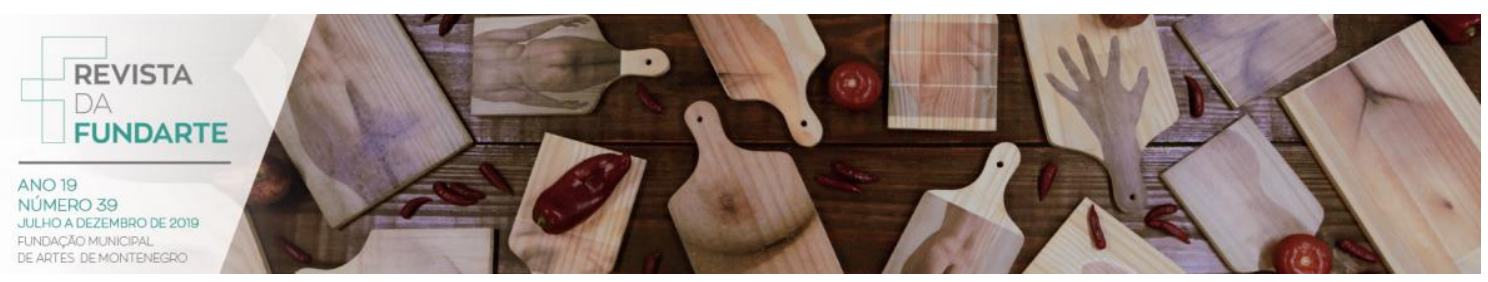

próprias trajetórias artísticas e acadêmicas, dos vínculos que eles estabelecem entre os seus Projetos e os conceitos em discussão, da reflexão crítica do contexto ${ }^{8}$ mais amplo no qual as investigações se desenvolvem e da interação com pesquisas em Artes Cênicas realizadas em âmbito acadêmico. Para tanto, os alunos são estimulados a assistir sessões de defesa e qualificação de Mestrado e Doutorado e a realizar leituras e discussões de trabalhos acadêmicos (especialmente as que se realizam no PPGAC e noutros Programas da área de Artes) que Ihes possibilitem visualizar aspectos metodológicos relacionados diretamente a questões e propósitos investigativos e ampliar seus conhecimentos sobre diversos temas e formas de abordagem.

$\mathrm{Na}$ culminância do processo realiza-se a atividade pedagógica sobre a qual este trabalho reflete, que se inicia a partir da escolha, leitura e fichamento de cinco trabalhos acadêmicos, do tipo dissertação ou tese, relacionados, de alguma forma (seja pela temática que envolve, pelo referencial teórico ao qual se alinha, ou pela metodologia da qual se utiliza), aos interesses dos alunos.

A apreciação dos textos acadêmicos escolhidos segue um "roteiro" de aspectos a observar, tais como: a contextualização do problema da pesquisa (sua localização, considerando os campos que atravessa); a justificativa, ou seja, as razões para a realização da pesquisa; a formulação do problema da pesquisa; o objetivo geral e os objetivos específicos do trabalho investigativo; as hipóteses; a teoria de referência e os conceitos-chave (de que forma são explicitados); os procedimentos metodológicos a serem adotados; a revisão de literatura; e as referências.

As primeiras impressões sobre as teses e dissertações lidas são apresentadas na sala de aula, mediante exposições orais e debates dos aspectos considerados relevantes para a elaboração dos chamados "exercícios" de produção textual. As normas e prazos para essa elaboração são estabelecidos no coletivo, visando à

\footnotetext{
8 Destaque para o complexo momento político atravessado pelo país, que culmina na eleição presidencial de 2018, e os retrocessos que o seu resultado representa à democracia, aos direitos humanos, à educação, à cultura e às artes.
}

SANTOS, Vera Lúcia Bertoni (et.al). Cinco escritos para um mosaico: produções textuais a partir de pesquisas acadêmicas em artes cênicas. Revista da FUNDARTE, Montenegro, p.124-148, ano 19, no 39, julho/dezembro de 2019.

Disponível em: http://.seer.fundarte.rs.gov.br/index.php/RevistadaFundarte/index> 20 de dezembro de 2019. 


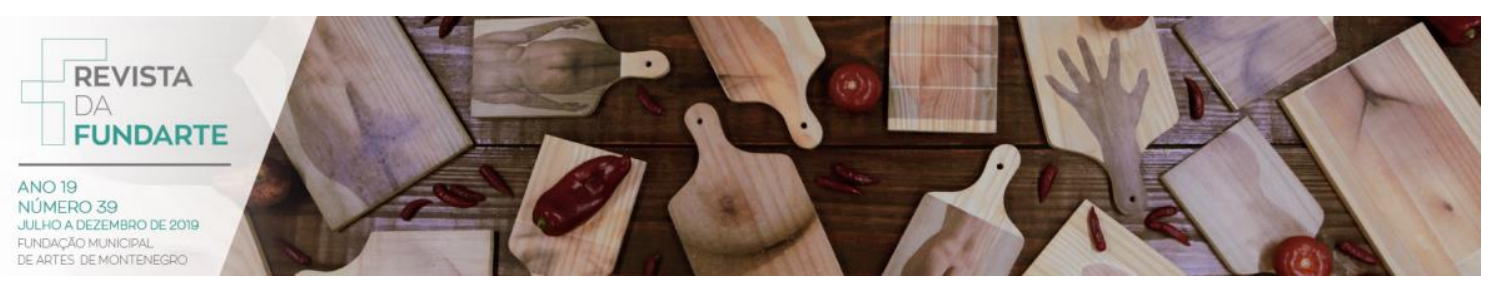

padronização dos textos; e os processos de escrita são acompanhados individualmente pela professora, por meio de comentários nos textos entregues, evidenciando aspectos a aprofundar, ou a aprimorar, nas versões finais.

Como resultado desse experimento pedagógico de caráter cooperativo, o grupo de pesquisadores do PPGAC da UFRGS apresenta as cinco produções textuais a seguir: um mosaico de sínteses reflexivas de trabalhos acadêmicos representativos de temáticas emergentes no campo das Artes Cênicas.

O texto I, da autoria de Silvana Bággio Ávila, reflete sobre a dissertação da pesquisadora Michele Almeida Zaltron, escolhida em função do interesse na contribuição do diretor e ator de teatro, pedagogo e teórico russo Konstantin Stanislávski. A investigação de Ávila, em andamento no PPGAC da UFRGS, propõe-se a identificar princípios motivadores da arte da fala do ator, no trabalho artístico e pedagógico de diferentes agentes criativos formadores brasileiros na área da atuação cênica, tendo por base aspectos do sistema de Stanislávski, como ação verbal e subtexto, considerados basilares à compreensão da concepção de fala cênica, numa perspectiva que alia tradição e contemporaneidade.

A perspectiva da interdisciplinaridade entre as Artes Cênicas e Visuais e a busca de compreensão do conceito de tarefas, de Anna Halprin, motivam Débora Souto Allemand, autora do texto II, a debruçar-se sobre a tese do artista e pesquisador Élcio Rossini, que se propõe a atualizar tal conceito, mediante a teorização de procedimentos próprios de criação em três performances. Dentre os propósitos artísticos e investigativos de Allemand, destacam-se as chamadas intervenções urbanas com Dança, compreendidas como formas atentivas de diálogo com o contexto mutável e imprevisível dos centros urbanos.

Justificado pelo interesse investigativo no campo da historiografia da Dança, e pela possibilidade de refletir sobre um trabalho panorâmico exemplar nesse sentido, Fellipe Santos Resende, autor do texto III, realiza o seu exercício a partir da dissertação de Mestrado de Carmi Ferreira da Silva. Situado nos campos da Dança e da História, o

SANTOS, Vera Lúcia Bertoni (et.al). Cinco escritos para um mosaico: produções textuais a partir de pesquisas acadêmicas em artes cênicas. Revista da FUNDARTE, Montenegro, p.124-148, ano 19, no 39, julho/dezembro de 2019.

Disponível em: http://.seer.fundarte.rs.gov.br/index.php/RevistadaFundarte/index> 20 de dezembro de 2019. 


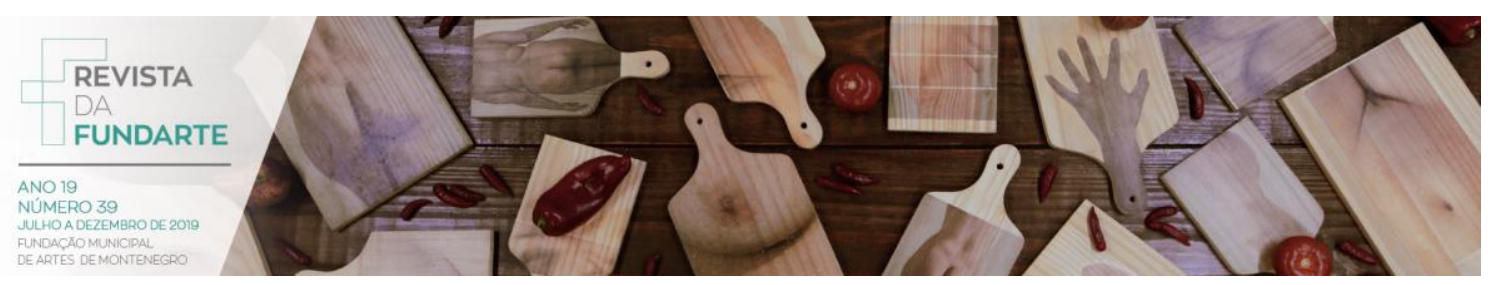

trabalho de Resende propõe-se a identificar vestígios da poética da coreógrafa e professora de dança Eva Schul, evidenciando traços da sua contribuição na formação de bailarinos contemporâneos sujeitos das suas propostas artísticas e pedagógicas.

O texto IV, escrito por lasmin D'Ornelas Ponsi a partir da dissertação de Mestrado de Juliana Canali Demori, tem sua escolha pautada pelo interesse na metodologia da pesquisa, que se fundamenta na chamada Poética Comparada, de Jorge Dubatti, aplicada à análise de espetáculos de teatro. Ponsi dedica-se à análise de espetáculos do artista circense Pierrot Bidon, cuja obra possibilita compreender o circo como linguagem em si, indicando uma dramaturgia circense, relacionada a poéticas de encenação do circo contemporâneo.

Completando o mosaico, o exercício V, elaborado por lassanã Martins, parte da dissertação de Mestrado da atriz e pesquisadora Edilaine Ricardo Machado, que reflete sobre o modo de como mulheres atrizes negras constituem a si mesmas a partir da formação teatral e do exercício profissional na cena de Porto Alegre (RS). Interessada em compor uma narrativa sobre a trajetória e os processos criativos de mulheres profissionais de teatro atuantes em Porto Alegre, Martins encontra, no trabalho de Machado, uma oportunidade de conhecer trajetórias de importantes atrizes, refletir sobre aspectos da formação e atuação dessas mulheres do teatro local, numa perspectiva diversa e alinhada a discursos contemporâneos sobre negritude e corporeidade.

\section{O TRABALHO DO ATOR SOBRE SI MESMO COMO HERANÇA DE STANISLÁVSKI ${ }^{9}$}

"Como chegar o mais próximo possível da compreensão do que Konstantin Serguéievitch Alekséiev Stanislávski (1863-1938) chamou de trabalho do ator sobre si mesmo?" Esta é a questão de partida da pesquisa de Michele Almeida Zaltron (2016,

${ }^{9}$ Escrito por Silvana Bággio Ávila.

SANTOS, Vera Lúcia Bertoni (et.al). Cinco escritos para um mosaico: produções textuais a partir de pesquisas acadêmicas em artes cênicas. Revista da FUNDARTE, Montenegro, p.124-148, ano 19, no 39, julho/dezembro de 2019.

Disponível em: http://.seer.fundarte.rs.gov.br/index.php/RevistadaFundarte/index> 20 de dezembro de 2019. 


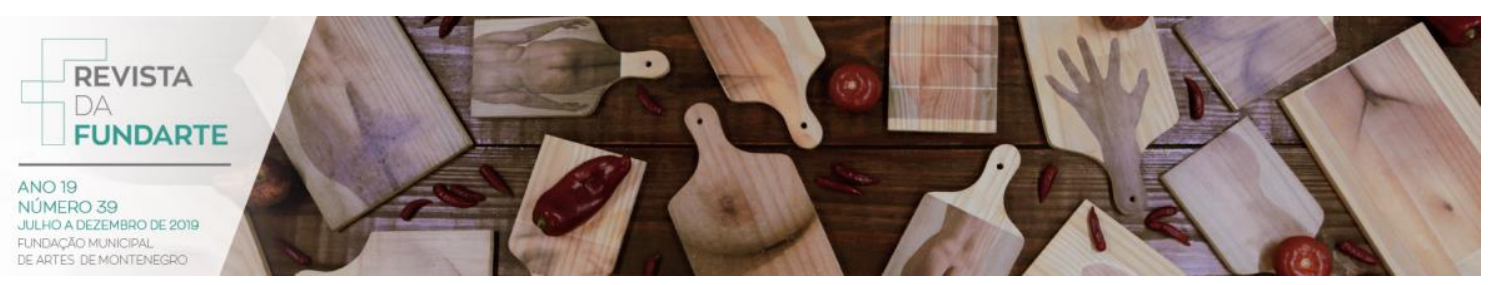

p.12), que se dedica ao aprofundamento da obra de um dos mais importantes mestres do teatro ocidental, tendo por base os estudos referenciais sobre o tema.

$\mathrm{Na}$ introdução da dissertação, a pesquisadora orienta o leitor em relação a três aspectos fundamentais a serem considerados: a sua inserção nos ensinamentos de Stanislávski, as questões de tradução e as noções de perejivánie e de voploschénie. A introdução é seguida por cinco capítulos: Capítulo I - O "sistema" e a natureza; Capítulo II - A arte da perejivánie; Capítulo III - O processo de criação da voploschénie; Capítulo IV - A herança viva de Stanislávski; Capítulo V - A Escola-estúdio do TAM: um olhar sobre a prática. Encerram a tese as considerações finais, as referências e os anexos.

Os elementos do trabalho (introdução, desenvolvimento e conclusão) são adequadamente estruturados, incluindo, em cada capítulo, uma série de subcapítulos que especificam a questão maior nele abordada; seguem as considerações finais do capítulo. Diante da organização estrutural, o leitor tem facilidade de acompanhar o raciocínio da autora, na exposição dos argumentos e das teorias que embasam a sua tese, cuja apresentação é fluida e inteligível.

Algumas das principais referências teóricas que sustentam a pesquisadora na elaboração da tese compreendem obras na língua russa, espanhola e portuguesa. A publicação russa mais recente das obras completas de Stanislávski, em nove tomos, ocorre entre 1988 e 1999, pela editora Iskusstvo. Outras publicações de importantes estudiosos russos incluem discípulos e artistas-pesquisadores de Stanislávski, como Grigori Kristi, Leopold Sulerjítski e Elena Poliakova. Cinco volumes das obras reunidas de Stanislávski, publicados nos anos 1980, pela editora Quetzal, com tradução direta para o espanhol das edições oriundas da primeira coletânea soviética das obras de Stanislávski, publicada entre 1954 e 1961. Além disso, o trabalho inclui as obras das professoras pesquisadoras Nair D’Agostini ${ }^{10}$, com a tese de doutorado "O Método de

\footnotetext{
10 Após sua formação no LGITMiK, entre 1978 a 1981, em Leningrado, hoje São Petersburgo, na URSS, D’Agostini trouxe para o Brasil o conhecimento teórico e prático do sistema de Stanislávski. Com essa base, a pesquisadora desenvolveu seu trabalho pedagógico e artístico no Curso de Artes Cênicas da

SANTOS, Vera Lúcia Bertoni (et.al). Cinco escritos para um mosaico: produções textuais a partir de pesquisas acadêmicas em artes cênicas. Revista da FUNDARTE, Montenegro, p.124-148, ano 19, no 39, julho/dezembro de 2019.

Disponível em: http://.seer.fundarte.rs.gov.br/index.php/RevistadaFundarte/index> 20 de dezembro de 2019.
} 


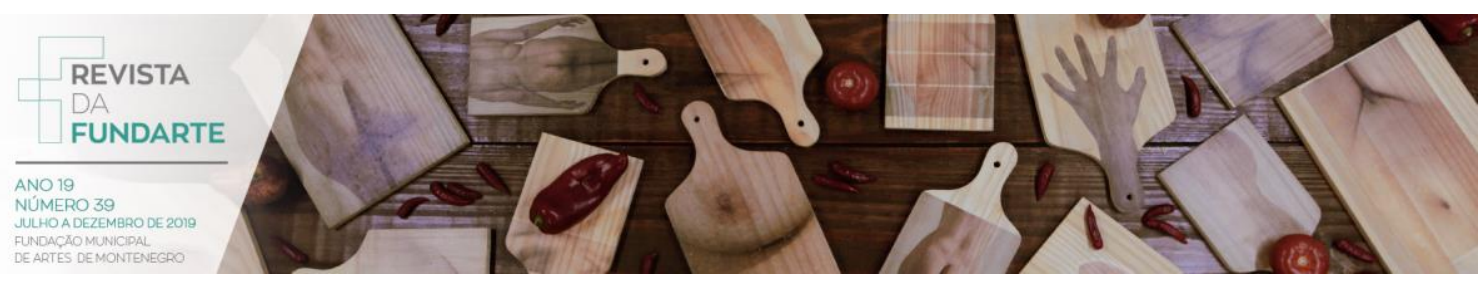

Análise Ativa de K. Stanislávski como base para a leitura do texto e da criação do espetáculo pelo diretor e ator"; e Elena Vássina ${ }^{11}$, autora de "Stanislávski: vida, obra e sistema".

A própria experiência de vida caracteriza a metodologia utilizada pela autora. A escolha consciente da pesquisadora é ressaltada na formulação do pensamento metodológico embasado naquilo que:

[...] foi se constituindo pela percepção das possibilidades que despontaram durante o caminho. Foi o próprio caminhar, provavelmente influenciado pela minha formação acadêmica e artística, a um só tempo, que desenhou 0 caminho da investigação. (ZALTRON, 2016, p.15).

$\mathrm{Na}$ leitura da dissertação, enumerei alguns destaques que evidenciam a relevância do trabalho de Zaltron, a começar pelo profundo entendimento do termo trabalho do ator sobre si mesmo na obra de Stanislávski, que amplia a compreensão de seu "sistema", contribuindo para a leitura de sua obra no Brasil. Esse entendimento foi possível pela escolha da pesquisadora em abordar o objeto de estudo "pelas terminologias que fundamentam e justificam o trabalho do ator sobre si mesmo", estudando-as no sentido original da língua russa: a noção de vivência, ou perejivánie; a noção de encarnação, ou voploschénie; e a noção de segunda natureza, ou vtoráia natura. Também contribuíram para isso a fundamentação teórica originária de publicações na língua russa, tanto da obra do próprio Stanislávski como de alguns de seus discípulos e de diretores-pedagogos ligados diretamente à herança pedagógica e artística do mestre russo.

Universidade Federal de Santa Maria (RS), onde atuou como professora. Como aluna no LGITMiK, estudou nos Cursos de "Maestria do Ator Dramático", de Arkádi Katsman (1921-1989) e "Direção Dramática", de Gueorgui Tovstonógov (1913-1988).

11 Vássina é pesquisadora e professora russa, formada na Faculdade de Letras da Universidade Estatal de Moscou Lomonóssov (MGU). Pós-doutora em Teoria e Semiótica de Cultura e Literatura pelo Instituto Estatal de Pesquisa da Arte (Rússia). Atualmente é professora de Literatura e Cultura Russa da USP. Em 2015 lançou, o livro "Stanislávski: vida, obra e sistema" pela editora da Funarte em co-autoria com Aimar Labak.

SANTOS, Vera Lúcia Bertoni (et.al). Cinco escritos para um mosaico: produções textuais a partir de pesquisas acadêmicas em artes cênicas. Revista da FUNDARTE, Montenegro, p.124-148, ano 19, nº 39, julho/dezembro de 2019.

Disponível em: http://.seer.fundarte.rs.gov.br/index.php/RevistadaFundarte/index $>20$ de dezembro de 2019. 


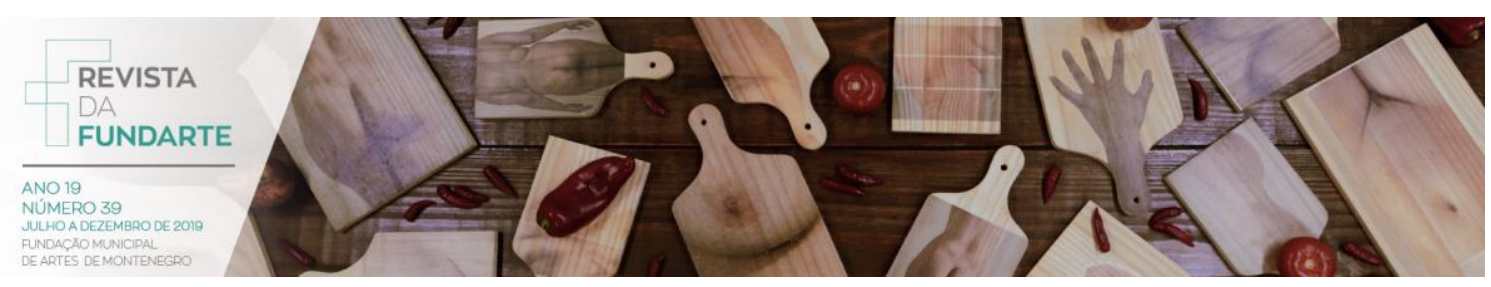

Aponto também a relevância de um trabalho que atinge o objetivo da pesquisadora: "enriquecer e ampliar a compreensão e a leitura que se têm hoje da obra de Stanislávski, sobretudo entre os estudantes brasileiros de Artes Cênicas" (ZALTRON, 2016, p.17). Como lembra a autora, os estudantes têm acesso somente a publicações em português das obras de Stanislávski, cujas traduções são feitas de forma indireta, ou seja, de publicações americanas, que trouxeram uma obra reduzida em relação à original em russo e que apresentaram diversos problemas de compreensão do "sistema" de Stanislávski.

Outro destaque é a concepção do "sistema" como uma "herança viva", representada, sobretudo, nos dias de hoje, pela Escola-Estúdio do Teatro de Arte de Moscou (Vladimir Nemirovich-Danchenko Moscow Art Theatre School), na Rússia, onde a pesquisadora realizou um estágio doutoral por um período de 10 meses, sob a supervisão do Prof. Dr. Vidmantas Silyunas. A experiência de estágio é trazida na tese em um pertinente capítulo, intitulado "A Escola-Estúdio do TAM: um olhar sobre a prática", que contribui para que o leitor vislumbre como as bases do "sistema" "vivem" nos diferentes processos artísticos e pedagógicos dos diretores-pedagogos da EscolaEstúdio hoje. Fica evidente o caráter dinâmico do "sistema", que se atualiza na relação particular que cada artista estabelece ao apoiar as pesquisas em suas bases. As entrevistas que a pesquisadora realizou com diretores-pedagogos da Escola-Estúdio são valiosos materiais que contribuem para o entendimento do "sistema" como uma "escola criativa", ou seja, "um conhecimento que não só permite, mas também requer que cada artista expresse a sua singularidade, o seu modo de ver e de perceber 0 mundo" (ZALTRON, 2016, p.179).

Saliento também a compreensão do trabalho do ator sobre si mesmo no trabalho de Stanislávski, a partir dos estudos da obra escrita na língua russa, possibilitados pelo conhecimento da pesquisadora em relação ao idioma, oferecendo aos leitores brasileiros a tradução para a língua portuguesa de algumas importantes citações e pensamentos do mestre russo e de alguns dos seus mais importantes discípulos e

SANTOS, Vera Lúcia Bertoni (et.al). Cinco escritos para um mosaico: produções textuais a partir de pesquisas acadêmicas em artes cênicas. Revista da FUNDARTE, Montenegro, p.124-148, ano 19, no 39, julho/dezembro de 2019.

Disponível em: http://.seer.fundarte.rs.gov.br/index.php/RevistadaFundarte/index> 20 de dezembro de 2019. 


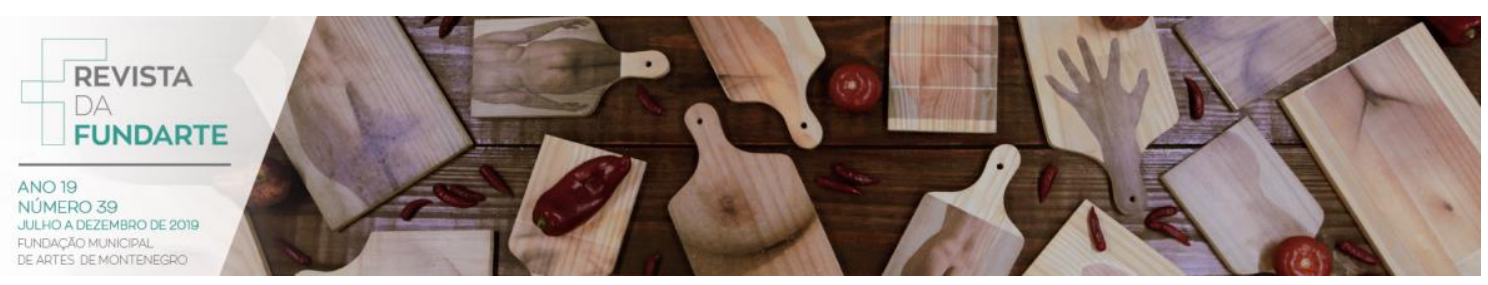

diretores-pedagogos, herdeiros de seu sistema. E a coerência da trajetória da autora como pesquisadora e o seu interesse concentrado no objeto da sua pesquisa, fatores que contribuem para a profundidade das reflexões trazidas na tese. Desde a graduação, quando se iniciou nos estudos do Método da Análise Ativa, através dos ensinamentos da professora D'Agostini, Zaltron vem se aprofundando no "sistema" de Stanislávski, desenvolvendo conhecimentos teórico-práticos no âmbito do Mestrado, com a dissertação intitulada "Imaginação e desconstrução em K. Stanislávski" e, no Doutorado, chegando a uma pesquisa que se potencializa com a experiência na Escola-Estúdio do TAM (Rússia).

Finalizo este exercício de escrita ressaltando a importância para o aprofundamento da pesquisa, o fato de Zaltron ter recebido conhecimentos da herança stanislavskiana na relação mestre-aprendiz com D’Agostini, que foi aluna de Gueorgui Tovstonógov (1913-1988), que, por sua vez, realizou sua formação no GITIS, Instituto Russo de Arte Teatral, com Maria Knébel (1898-1985), colaboradora de Stanislávski nos últimos anos de seu trabalho laboratorial e na elaboração do novo método de ensaios, sendo ela responsável por nomeá-lo Método da Análise Ativa.

\section{ANNA HALPRIN E ÉLCIO ROSSINI: O QUE FIGURA DOS FANTASMAS? ${ }^{12}$}

A motivação de realizar a resenha comentada da tese do artista visual professor e pesquisador Élcio Rossini, deu-se em função da minha aproximação com o conceito de "tarefas", de Anna Halprin, e da vontade de aprofundar o assunto. Além disso, considerei o aspecto interdisciplinar da tese, que se desenvolve na intersecção das Artes Cênicas com as Artes Visuais, característica das pesquisas artísticas contemporâneas.

Situada na linha de pesquisa Poéticas Visuais, do Programa de Pós-Graduação em Artes Visuais da UFRGS, a tese reflete sobre uma performance criada pelo artista,

12 Escrito por Débora Souto Allemand.

SANTOS, Vera Lúcia Bertoni (et.al). Cinco escritos para um mosaico: produções textuais a partir de pesquisas acadêmicas em artes cênicas. Revista da FUNDARTE, Montenegro, p.124-148, ano 19, ํo 39, julho/dezembro de 2019.

Disponível em: http://.seer.fundarte.rs.gov.br/index.php/RevistadaFundarte/index> 20 de dezembro de 2019. 


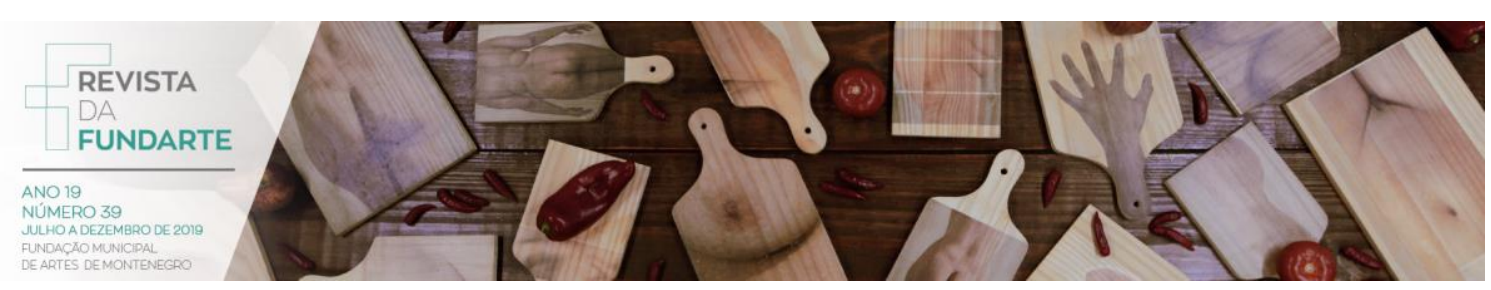

que the possibilita discutir assuntos como tarefas, tempo, duração, repetição e atuação/não-atuação. O tema do trabalho são os procedimentos de criação de Rossini e a questão da pesquisa relaciona-se à atualização da noção de tarefas, que se dá a partir da reflexão sobre performances criadas pelo artista, tendo como foco principal a obra "Figuras e Fantasmas" (2005), da qual se desdobram outras duas performances.

Para estruturar o trabalho, o autor inicia por uma breve introdução da pesquisa, expondo suas questões, objetivos de estudo e apresentando um resumo rápido das tarefas em foco; a seguir, faz um apanhado das suas performances e, por fim, enfoca a metodologia do estudo. No corpo do texto, ele traz pequenos subcapítulos, nos quais reflete sobre referências artísticas, o próprio trabalho e conceitos teóricos em foco na tese.

O capítulo 1 é, na minha opinião, "a cereja do bolo", pois aborda especificamente o tema do trabalho, ou seja, enfoca as tarefas. Trata também de seus antecedentes, como a pesquisa de mestrado do autor e a experiência como professor substituto no Departamento de Arte Dramática (DAD) da UFRGS, além das suas relações com os estudos de Halprin (a partir de 1957) e com as ações físicas de Grotowski (década de 1960). O capítulo 2 inicia com a descrição e análise da performance "Figuras e Fantasmas", trazendo conceitos de atuação. Os capítulos seguintes, 3 e 4, trazem a discussão sobre as noções de duração e repetição, respectivamente, com aspectos teóricos relacionando com referências artísticas e com sua performance. Finalmente, o capítulo 5 fala sobre as performances "Palavras" e "Ato sem título", desdobramentos de "Figuras e Fantasmas", trazendo ponderações sobre temas que se abriram no caminho de transformação da performance original, encaminhando-se para a conclusão do trabalho, que trata da atualização das tarefas.

Os principais referenciais teóricos e artísticos utilizados por Rossini são: Anna Halprin (1954), com o conceito de tarefas; Jerzy Grotowski (1960), com as ações físicas; Michael Kirby (1998) e Renato Ferracini (2009), com suas discussões sobre atuação e não-atuação; Marina Abramovic (1970) e Robert Wilson (1964), agregando

SANTOS, Vera Lúcia Bertoni (et.al). Cinco escritos para um mosaico: produções textuais a partir de pesquisas acadêmicas em artes cênicas. Revista da FUNDARTE, Montenegro, p.124-148, ano 19, no 39, julho/dezembro de 2019.

Disponível em: http://.seer.fundarte.rs.gov.br/index.php/RevistadaFundarte/index> 20 de dezembro de 2019. 


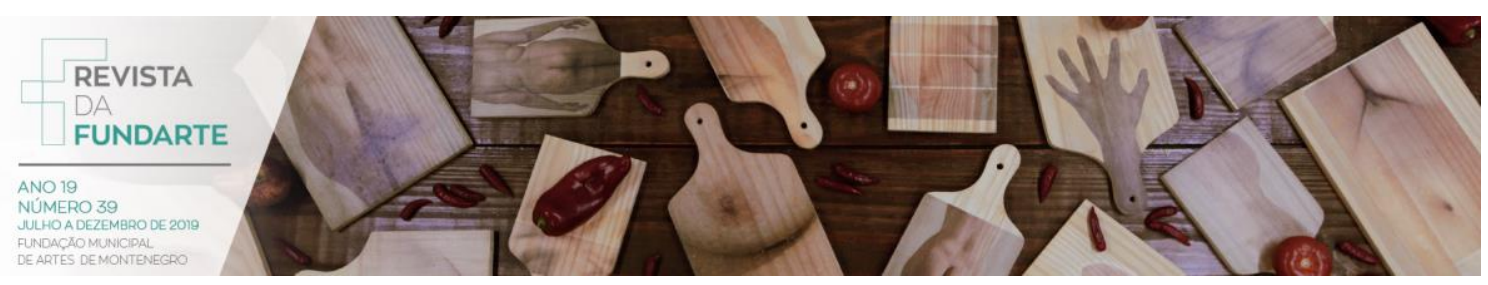

reflexões sobre o tempo; Pina Bausch (1978) e Yvonne Rainer (1971), com suas noções de repetição; Erving Goffman (2007), e seus estudos sobre performance, atuação e cotidiano; Sally Banes (1998), acerca da pós-modernidade; Gaston Bachelard (1972), com reflexões sobre fantasmas; Walter Benjamin (1992), e suas conceituações sobre reprodutibilidade da obra de arte; e, por fim, Hans- Thies Lehmann (2007), acerca do teatro pós-dramático, da repetição e da contemporaneidade.

A metodologia do trabalho aposta na

reconstituição do processo de criação desde a elaboração da performance propriamente dita [Figuras e Fantasmas] até a experiência das apresentações públicas incluindo as modificações que o encontro com o público produziu e o modo pelo qual essas modificações foram incorporadas ao trabalho. (ROSSINI, 2011, p. 10).

Assim, relaciona teoria e prática artística e trabalha com uma narrativa que mapeia os acontecimentos e depende da memória do autor, pois consiste numa reconstituição de performances realizadas anteriormente à escrita da tese e reflete sobre como as experiências de encontro com o público modificaram o trabalho, desdobrando-se em outras performances, analisadas no capítulo 5 .

Como aspectos relevantes da escrita de Rossini, ressalto a apresentação e a reflexão de referências teóricas em meio às referências artísticas, utilizadas para discutir aspectos do trabalho do autor, o que resulta num texto notadamente imagético, no qual os conceitos são exemplificados nas práticas realizadas por outros artistas.

Dentre os principais resultados da pesquisa, Rossini aponta o procedimento de tarefas como porta de entrada para a criação de performances. Na sua concepção, apresentar os elementos estruturais das tarefas - duração, não-atuação e repetição - e reorganizá-los na contemporaneidade constitui o aspecto principal na atualização dos procedimentos de criação em arte.

SANTOS, Vera Lúcia Bertoni (et.al). Cinco escritos para um mosaico: produções textuais a partir de pesquisas acadêmicas em artes cênicas. Revista da FUNDARTE, Montenegro, p.124-148, ano 19, no 39, julho/dezembro de 2019.

Disponível em: http://.seer.fundarte.rs.gov.br/index.php/RevistadaFundarte/index> 20 de dezembro de 2019. 


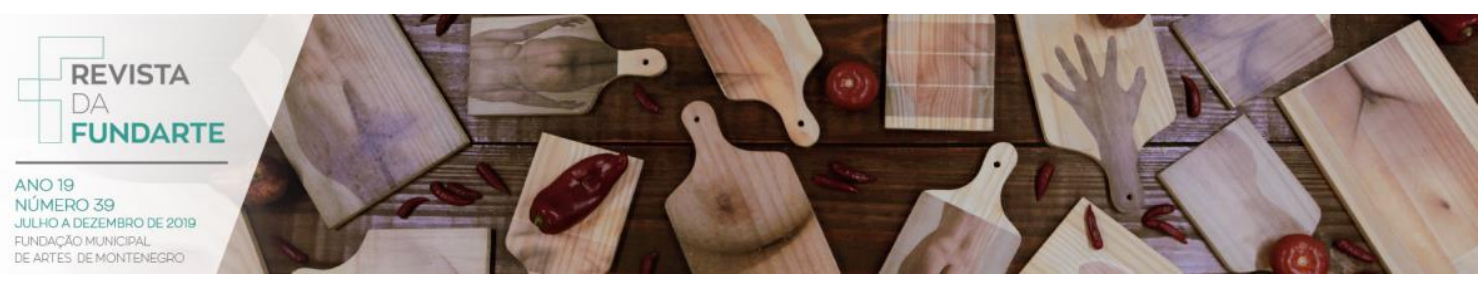

\section{FAZER HISTORIOGRÁFICO EM DANÇA NO BRASIL ${ }^{13}$}

Os motivos da escolha da dissertação de Carmi Ferreira da Silva decorrem, inicialmente, de uma identificação pessoal, como doutorando e sujeito leitor, com a área da historiografia da Dança. Na busca de estudos de referência desse campo de pesquisa, com o qual busco estabelecer relações, encontro, no trabalho de Silva, um exemplo importante de material crítico e reflexivo para as Artes Cênicas, em especial para a Dança, na medida em que contextualiza um panorama geral deste campo de conhecimento, lança reflexões sobre as tendências vigentes e tradicionalmente elegidas neste escopo, e amplia a lente de metodologias possíveis frente ao fazer historiográfico em Dança.

$\mathrm{Na}$ busca por subsídios teóricos e no desejo de ampliar uma rede de conceitos, reflexões e contribuições para respaldar, inspirar e "dar às mãos" a mim e à minha orientadora, professora doutora Mirna Spritzer, na pesquisa em andamento no PPGAC da UFRGS ${ }^{14}$, o estudo de Silva constitui uma possibilidade de estudar uma refinada produção teórica no campo, aproximando-me de suas compreensões e raciocínios, para pensar a demanda epistemológica na qual meu estudo pretende se desenhar.

Assim, considero valiosa a oportunidade de trazer algumas reflexões instigadas durante a leitura do trabalho e a elaboração deste parecer reflexivo, que encarei como um exercício experimental importante ao processo de qualificação do doutorado. Guardadas as devidas proporções de espaço e de tempo de realização deste texto, espero trazer contribuições disparadoras de questões pertinentes ao tema em estudo.

\footnotetext{
${ }^{13}$ Escrito por Fellipe Santos Resende.

14 Provisoriamente denominada "Reverberações poéticas em Dança: rastros e atualizações a partir do legado de Eva Schul", a pesquisa investiga a poética da dança contemporânea da mestra, coreógrafa e bailarina Eva Schul e suas reverberações nos discursos e condutas artísticas de alguns alunos e exalunos que tiveram vivências cênicas e formativas com ela. Inicia-se por um escaneamento historiográfico da matriz formativa de Schul, para, a partir de seus mestres/principais influências e de sua trajetória artística e docente propriamente dita, estudar como esses conhecimentos e elementos são acessados, desdobrados, atualizados: por ela e pelos corpos com quem a artista estabelece relações nas suas danças, numa indefinida posterioridade/contemporaneidade.
}

SANTOS, Vera Lúcia Bertoni (et.al). Cinco escritos para um mosaico: produções textuais a partir de pesquisas acadêmicas em artes cênicas. Revista da FUNDARTE, Montenegro, p.124-148, ano 19, ㄲo 39, julho/dezembro de 2019.

Disponível em: http://.seer.fundarte.rs.gov.br/index.php/RevistadaFundarte/index $>20$ de dezembro de 2019. 


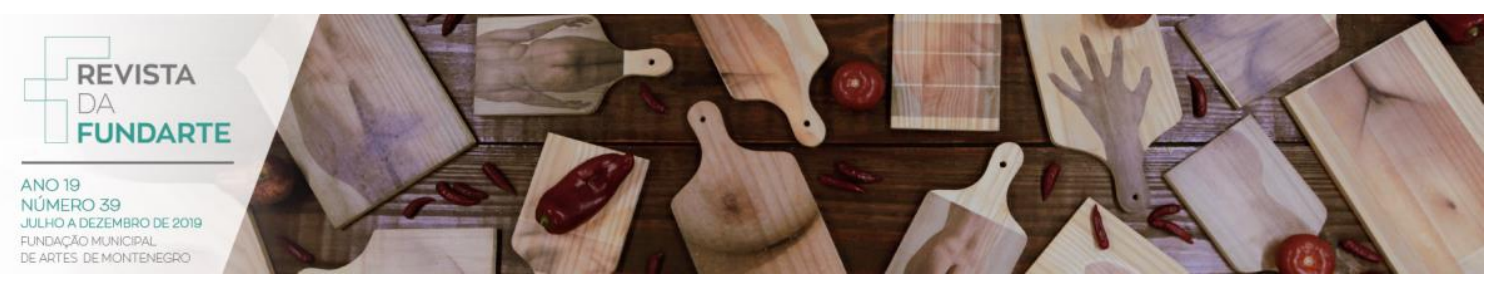

Num primeiro olhar, é possível situar que o foco da dissertação é contribuir para o avanço da pesquisa na área da Dança, abordando temáticas no campo da História da Dança e seus modos de agir, designados historiografia. Nessa intenção, Silva vale-se de uma reflexão sobre as estratégias e métodos utilizados na construção de narrativas históricas dessa área, levantando dados e problematizando as convenções da História Tradicional e críticas a esse modelo, especialmente as trazidas por teóricos franceses do movimento chamado Nova História.

O autor levanta três aspectos que caracterizam a compreensão da escrita da história: o primeiro é a predominância de publicações da área no século passado, no formato de livros, que tinham aproximadamente o mesmo conteúdo e formatação (baseando suas reflexões em estilos hegemônicos de dança, como o balé clássico, a dança expressionista alemã e a dança moderna americana); o segundo aspecto são as estruturas informativas seguindo um padrão tradicional de livros de História, com informações colocadas em blocos separados, dando uma ideia de distanciamento dos eventos e uma linearidade determinante (inferindo causalidade); e, por fim, chama atenção para o fato de que os poucos fragmentos existentes sobre a História da Dança brasileira limitavam-se a narrar trechos das companhias e artistas de balé clássico do Rio de Janeiro ou São Paulo.

De modo geral, o estudo refere-se a um contexto complexo, com algumas tendências, mas não necessariamente determinações. A discussão aponta para uma questão sociocultural bem ampla de representatividade e padrões mais valorizados de pesquisa no campo da Dança, no qual estão combinados, dentre outros motivos, aspectos mercadológicos, políticos e ideológicos que resistem a uma ampliação temática e ao ato de estudar documentalmente nestes moldes outras danças que não constituíam um mainstream dos gêneros e técnicas corporais da época.

Destaco como fundamental a crítica de Silva em relação à falha na cobertura equânime das historiografias sobre danças no Brasil. Acredito que este seja um pensamento quase que unânime entre nossos pares no que toca a essa necessidade,

SANTOS, Vera Lúcia Bertoni (et.al). Cinco escritos para um mosaico: produções textuais a partir de pesquisas acadêmicas em artes cênicas. Revista da FUNDARTE, Montenegro, p.124-148, ano 19, nº 39, julho/dezembro de 2019.

Disponível em: http://.seer.fundarte.rs.gov.br/index.php/RevistadaFundarte/index> 20 de dezembro de 2019. 


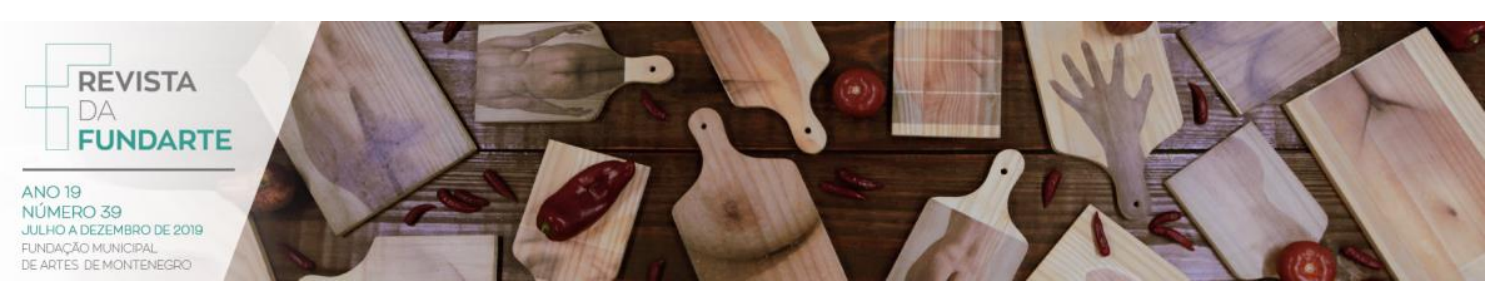

isto é, muito se deseja que esse movimento de mudanças paradigmáticas e metodológicas seja mais explorado e levado adiante. E o trabalho de Silva lança importantes provocações nesse sentido.

O autor faz uma crítica contundente às estruturas tradicionais usadas na criação de histórias, apontando tendências de generalização, superficialidade e causalidade, além de uma insuficiente reflexão sobre as informações de cada contexto. Tal crítica é compreensível e muito válida, pois mobiliza estruturas metodológicas padronizadas e muitas vezes sacralizadas, além de apresentar modelos alternativos de se historicizar fatos e acontecimentos do referido campo. Uma exploração mais ampla dos motivos socioculturais cabíveis a essa época em que a História Tradicional se fez tão forte me pareceria costurar com mais nitidez os porquês (ainda que hipotéticos) dessa hegemonia por tanto tempo, uma vez que detalhes como as demandas produtivas e as lógicas de consumo desses produtos tradicionais, nas especificidades do século $X X$ e XXI, podem trazer motivos importantes de entendimento ainda não explicitados.

Pela perspectiva de Jacques Le Goff, Lucien Febvre e Marc Bloch, da Escola de Annales - Paris, França, são sutilmente trazidos aos textos teóricos que encabeçaram um importante movimento de proposições históricas alternativas à História Tradicional, superando a passividade analítica, preenchendo lacunas pré-existentes, aprofundandose na crítica e na contextualização dos micro acontecimentos e detalhes levantados. A leitura leva a pensar que as contribuições desses pensadores reverberam positivamente no presente e seguirão reverberando aos que virão, disparando debates e suscitando questões importantes. E aqui saliento o fato da dissertação de Silva enfatizar a força dos métodos da História Tradicional e da Nova História sem polarizálos ou deixá-los cair numa dinâmica de juízo de gosto, ou valor.

Dentre as muitas passagens relevantes do texto, destaco uma discussão referente à oralidade, conduta humana que, segundo o autor, antecede as práticas históricas de escrita e leitura, sendo precedida pelos gestos e ações, que, por sua vez, permitiam a comunicação e a replicação das informações construídas no intelecto e

SANTOS, Vera Lúcia Bertoni (et.al). Cinco escritos para um mosaico: produções textuais a partir de pesquisas acadêmicas em artes cênicas. Revista da FUNDARTE, Montenegro, p.124-148, ano 19, no 39, julho/dezembro de 2019.

Disponível em: http://.seer.fundarte.rs.gov.br/index.php/RevistadaFundarte/index> 20 de dezembro de 2019. 


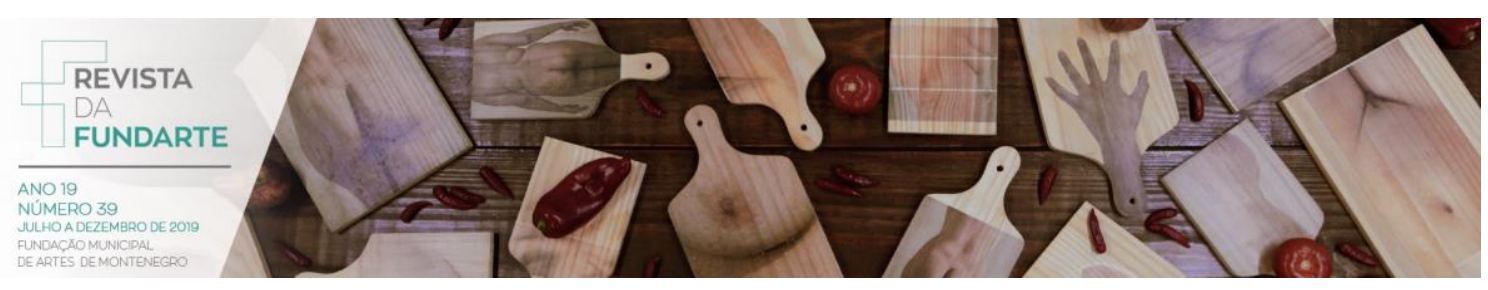

vivências dos sujeitos. $O$ trecho a seguir refere-se à outra ideia expressa no texto, que considero muito oportuna: "A História da Dança brasileira parece estar escrita no seu próprio 'recurso' de expressividade, no corpo brasileiro" (SILVA, 2012, p. 23). A partir dessa colocação, aparentemente óbvia, Silva valoriza outras dimensões da história que não a escrita, iluminando fortemente outras fontes de materialidades e saberes encarnados, ou seja, vestígios que escapam aos registros textuais, e que trazem qualidades próprias do discurso falado e dançado.

Segundo o autor, a historiografia da Dança enfrentava um grande desafio no século passado, pois sua natureza corporal e a ausência de certo aporte teórico reforçava um estereótipo que enxergava os bailarinos e demais artistas/pesquisadores da Dança como carentes de intelectualismo. Assim, jornalistas e outros profissionais conseguiram legitimidade necessária para ocupar a maioria dos espaços de elaboração das teorias e narrativas da Dança, apropriando-se de uma fatia expressiva desse mercado. Pensando essas questões na contemporaneidade, questiono: não estaríamos ainda vendo essa dinâmica ser reproduzida, ao termos uma predominante representatividade nas atribuições de críticos de arte, curadores e responsáveis administrativos pelas artes sendo configuradas por jornalistas, filósofos e demais teóricos não diretamente ligados ao campo da Dança? O quanto desse modelo é reproduzido e alimentado pelos nossos próprios discursos e práticas?

O estudo de Silva indica que, nas primeiras décadas do século passado, o interesse enfático na prática artística desviou os olhares dos estudiosos da Dança da prática historiográfica. Mas, por outro lado, relaciona esse aparente desinteresse às limitações dos métodos de escrever história usados tradicionalmente, que não contemplavam conhecimentos desviantes, ou afastados de um formato hegemônico e aceito como simbolicamente válido (ou seja, que envolvessem materiais diretamente corpóreos, ou movimentos diretamente dançados).

Ao analisar a formação dos autores de livros de História da Dança no Brasil, são destacados grupos mais próximos às áreas da Dança, História e Música, com uma

SANTOS, Vera Lúcia Bertoni (et.al). Cinco escritos para um mosaico: produções textuais a partir de pesquisas acadêmicas em artes cênicas. Revista da FUNDARTE, Montenegro, p.124-148, ano 19, no 39, julho/dezembro de 2019.

Disponível em: http://.seer.fundarte.rs.gov.br/index.php/RevistadaFundarte/index> 20 de dezembro de 2019. 


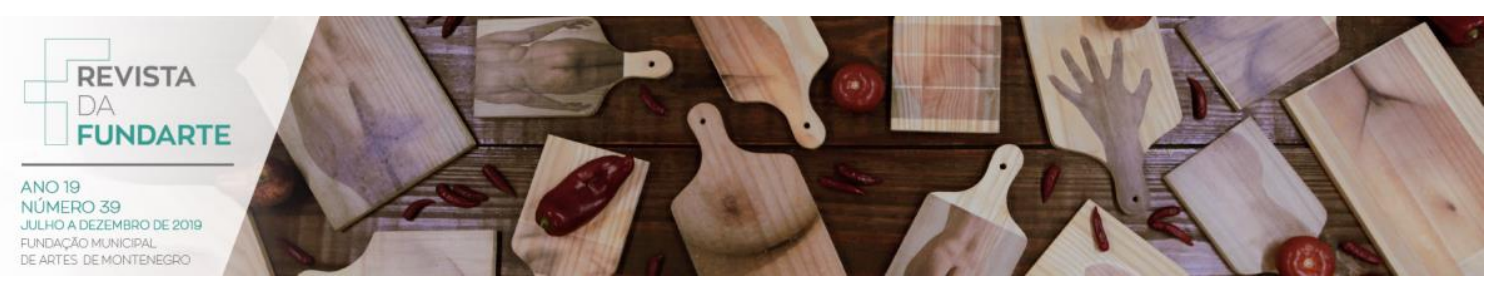

predominante presença de autores com formação como bailarino. Conforme apontado por Silva, embora muitas dessas publicações sejam importantes para a memória e historiografia da Dança, elas não conferem aos seus autores, na maioria dos casos, a posição de historiador, visto que se limitam a reproduzir histórias já narradas, obtidas sem uma pesquisa de dados ou fontes, privadas do conhecimento dos métodos historiográficos, ou seja, sem qualificação necessária para este tipo de pesquisa. Nesse sentido, o texto suscita reflexões interessantes, mas não conclusivas, sobre a figura do historiador na contemporaneidade: os limites e possibilidades da pesquisa historiográfica, seus métodos, suas condições de legitimidade, dentre outras.

De toda forma, Silva indica pistas para se construir uma crítica sobre modos limitantes que geralmente aprendemos e reproduzimos na busca do conhecimento de natureza histórica. Embora a internet e demais espaços virtuais tenham democratizado as possibilidades de publicação de produções que de outra forma talvez não circulassem, sem os cuidados necessários, essa plataforma comunicacional acaba difundindo conteúdos superficiais, e mesmo equivocados. Por outro lado, a academia, mesmo parecendo propícia para que caibam estes novos modos de registro e construção da História da Dança, não é inteiramente determinante na construção de um trabalho historiográfico de qualidade, muito menos imune a falhas e desacertos. Assim, cabe frisar que a responsabilidade está nas mãos do pesquisador em Dança: sendo o protagonismo de um planejamento efetivo, a aplicação metodológica e o rigor de escrita na artesania historiográfica de fatores que estão em sua posse.

No processo de leitura da Dissertação e elaboração deste exercício, foi notável a solidez da trajetória do autor no PPGDança da UFBA, berço acadêmico da Dança no Brasil, e valiosa a sua contribuição para a área historiográfica da Dança e de outras áreas no Brasil e no mundo.

SANTOS, Vera Lúcia Bertoni (et.al). Cinco escritos para um mosaico: produções textuais a partir de pesquisas acadêmicas em artes cênicas. Revista da FUNDARTE, Montenegro, p.124-148, ano 19, no 39, julho/dezembro de 2019.

Disponível em: http://.seer.fundarte.rs.gov.br/index.php/RevistadaFundarte/index> 20 de dezembro de 2019. 


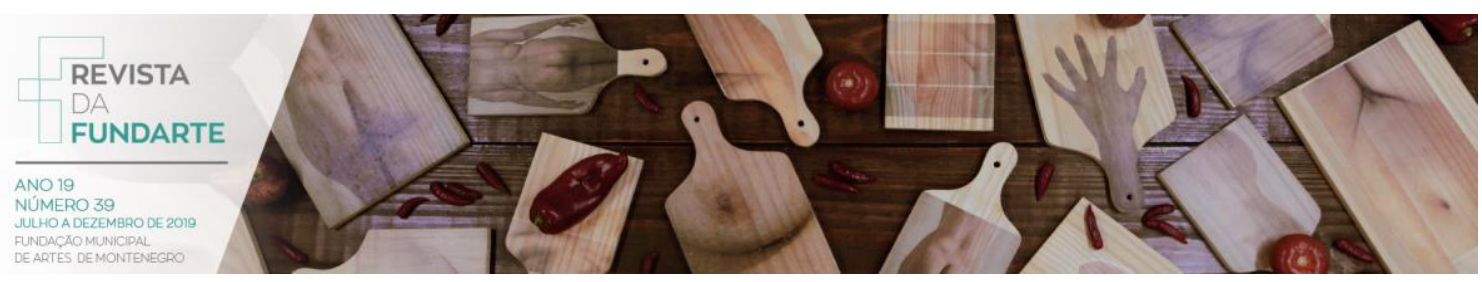

\section{PROCEDIMENTOS DE ANÁLISE DE POÉtICAS TEATRAIS SEGUNDO PRINCÍPIOS DE JORGE DUBATTI ${ }^{15}$}

O motivo da escolha da dissertação Juliana Canali Demori (2016) para a realização deste parecer é justamente o fato da pesquisa apresentar a aplicação de uma metodologia fundamentada nos estudos sobre a Poética Comparada, desenvolvidos pelo teórico argentino Jorge Dubatti (2003, 2007 e 2008), na análise das poéticas dos espetáculos teatrais do Grupo de teatro gaúcho Miseri Coloni ${ }^{16}$

De modo geral, a pesquisa possui relevância no sentido de contribuir com os estudos ditos contextualizados, ou territorializados, segundo Dubatti, confrontados com conceitos e noções acerca do Teatro Comunitário. De maneira acertada e coerente no emprego dessa metodologia, tendo como premissa os estudos do teórico em questão, que sustentam o trabalho, Demori apropria-se notadamente das mais diversas e complexas noções (e suas subdivisões) ligadas aos princípios de Dubatti, o que torna a leitura prazerosa e transmite segurança ao leitor.

A escrita configura-se de maneira clara, objetiva e bem organizada, proporcionando compreensão da lógica e do raciocínio que orienta o texto, que é ricamente complementado com imagens, como fotos, programas e recortes de jornais, facilitando o entendimento e a visualização do trabalho do grupo, de acordo com a evolução do pensamento durante todo o percurso da dissertação.

O trabalho é organizado em três capítulos e legitima-se de acordo com o desenvolvimento do tema, que é elucidado na Introdução e retomado nas Considerações Finais. O capítulo 1 compreende uma abordagem a respeito da imigração italiana na Serra Gaúcha, observando suas tradições e costumes a fim de

\footnotetext{
${ }^{15}$ Escrito por lasmin D'Ornelas Ponsi.

${ }^{16}$ O grupo teatral Miseri Coloni foi fundado na cidade de Caxias do Sul/RS (1980), por um grupo de amigos: Antônio Parenti, Arcangelo Zorzi Neto (Maneco), Auri Pasqual Paraboni, Hugo Lorensatti, João Wianey Tonus, Lídia Tonus, Nadir Tonus e Pedro Parenti Neto. A trupe circulou por várias cidades de todo o país, além de ter realizado duas temporadas na Itália. Em 1992, a Associação Cultural Miseri Coloni é considerada Utilidade Pública pelo prefeito de Caxias do Sul, Mansueto Serafim Filho e recebeu o Prêmio Troféu Expressão Cultural da Assembleia Legislativa do Estado do RS, em 1999. (Site oficial: https//misericoloni.com.br).
}

SANTOS, Vera Lúcia Bertoni (et.al). Cinco escritos para um mosaico: produções textuais a partir de pesquisas acadêmicas em artes cênicas. Revista da FUNDARTE, Montenegro, p.124-148, ano 19, no 39, julho/dezembro de 2019.

Disponível em: http://.seer.fundarte.rs.gov.br/index.php/RevistadaFundarte/index $>20$ de dezembro de 2019. 


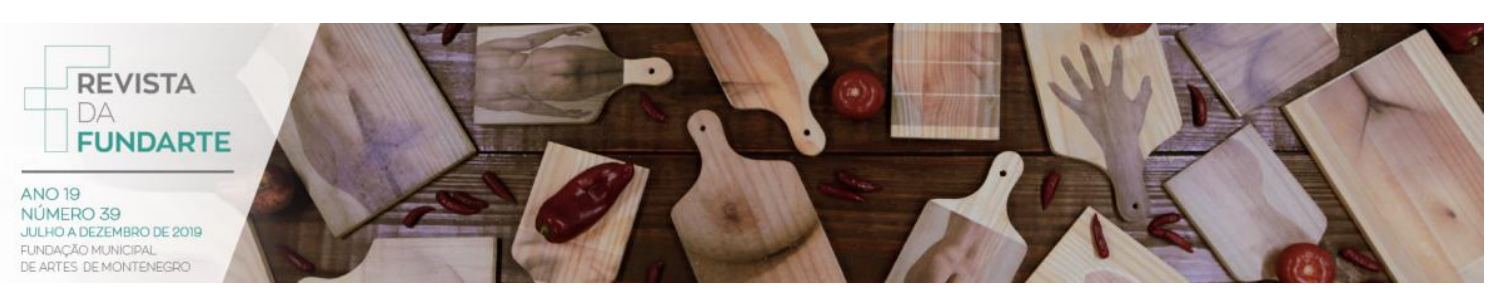

captar aspectos da identidade da comunidade de Caxias do Sul, visto que a linguagem do grupo é intrinsecamente calcada nesse contexto cultural territorializado. Inicialmente, o capítulo discorre sobre a vinda dos imigrantes italianos, seu processo de instalação e adaptação na cidade, apontando os fatos históricos numa abordagem bastante esclarecedora e sem ser, de forma alguma, exaustiva. De fato, é essa explanação que possibilita um entendimento mais aprofundado do propósito do grupo, de revisitar suas origens culturais típicas, bem como possibilita a compreensão da sua linguagem e de suas propostas estéticas e temáticas específicas e singulares, como, por exemplo, o caso do personagem Nanetto Pipetta.

A autora constata, no trabalho do grupo, uma forma de comunicação imediata, uma "relação afetiva" com seu público, que, por sua vez, se reconhece ao identificar-se com os personagens imigrantes. Destaco ainda a diversidade e qualidade de materiais que compõem o texto, como os apêndices (as entrevistas com os componentes do grupo) e os anexos (vídeos dos espetáculos). O rico material apresentado demonstra 0 compromisso da pesquisadora com o seu objeto de investigação. De fato, o material produzido permite conhecer a maneira de como se desenvolve o trabalho artístico do grupo, seus processos de criação, suas escolhas e procedimentos. Sendo assim, a dissertação torna evidente a questão do "convívio" (Dubatti, 2003) entre o grupo e a comunidade, através das apresentações nos mais variados locais e eventos, visto que frequentemente, o grupo se desloca até seu público, sendo recebido com jantares e encontros de confraternização.

Outro aspecto a destacar é a detalhada narrativa sobre a trajetória do Miseri Coloni, que incita no leitor uma curiosidade e até mesmo apreço pelo trabalho artístico e engajado dos seus integrantes, independentemente do acesso aos seus espetáculos. Além desse aspecto histórico relevante da pesquisa de Demori, salienta-se o estabelecimento de relações entre os conceitos de identidade, cultura e território. Trazendo como referência os estudos de Stuart Hall (2006), no que tange à ideia de um processo de "tradução", Demori (2016, p. 48) ressalta que "a identidade do imigrante

SANTOS, Vera Lúcia Bertoni (et.al). Cinco escritos para um mosaico: produções textuais a partir de pesquisas acadêmicas em artes cênicas. Revista da FUNDARTE, Montenegro, p.124-148, ano 19, no 39, julho/dezembro de 2019.

Disponível em: http://.seer.fundarte.rs.gov.br/index.php/RevistadaFundarte/index> 20 de dezembro de 2019. 


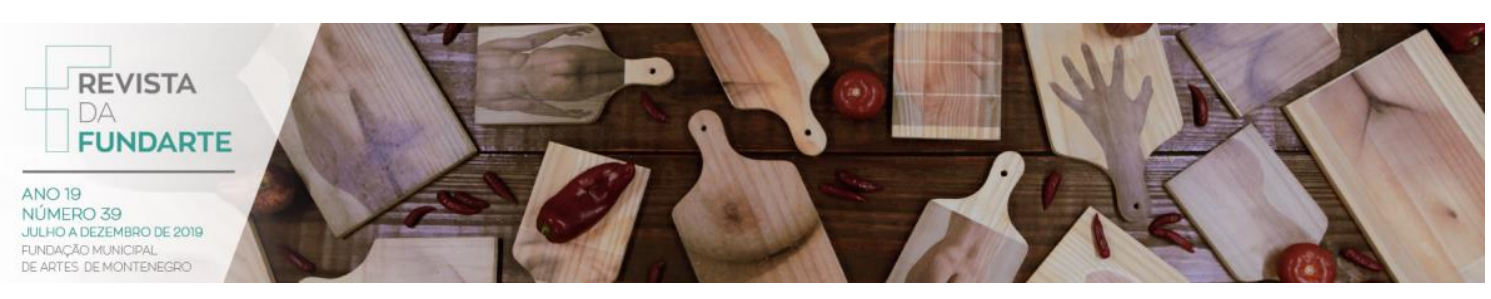

italiano acabou sendo atravessada por uma cultura diferente daquela que era a sua de origem", ou seja, a autora evidencia a compreensão de uma identidade constituída de uma cultura adaptada ou "traduzida" para o contexto da imigração na Serra Gaúcha. Outro aspecto explorado na dissertação é a relação entre as noções de identidade e território desenvolvidos por Edevaldo A. Souza e Nelson R. Pedron (2007), compreendendo a cultura italiana como "um território simbólico, que foi desterritorializado durante o processo de imigração e reterritorializado em solo brasileiro" (DEMORI, 2016, p. 49). Portanto, o texto transita entre esses conceitos de maneira coerente e na medida certa, ou seja, como suporte à construção da análise indutiva proposta pela pesquisadora. Mesmo assim, é através dessa descrição minuciosa da história e feitos do grupo que torna possível para o leitor o entendimento do que seria essa construção de identidade.

O capítulo 2 trata dos princípios e procedimentos para a análise das poéticas segundo Dubatti, o que possibilita compreender, de maneira precisa e acessível, como se dá o processo de análise indutiva empreendido na pesquisa, na medida em que a autora analisa a obra na sua complexidade (dimensão histórica, cultural e geográfica) e compreende o acontecimento teatral e sua poiésis (DEMORI, 2016, p. 53). Ainda no capítulo 2, consta uma descrição detalhada, as propostas estéticas e temáticas, bem como dos processos de criação de cada um dos espetáculos do que constituem o corpus em questão; e uma reflexão aprofundada acerca da noção de Teatro Comunitário, a partir de referências que permitem uma aproximação entre as teorias de Marcela Bidegain (2007) e Márcia Pompeo Nogueira (2007, 2008, 2011) confrontadas com a Poética Comparada, de Dubatti. Novamente o emprego das proposições de Dubatti acompanha a análise das poéticas de forma justa, coerente e com fluidez.

O capítulo 3 parte da teorização do conceito de "acontecimento teatral" e da explanação das suas subdivisões (o acontecimento convivial, 0 poético e 0 expectatorial), conforme Dubatti (2007), relacionado com as teorias acerca da produção de subjetividade e da singularização. Mais uma vez, Demori demonstra excelência ao

SANTOS, Vera Lúcia Bertoni (et.al). Cinco escritos para um mosaico: produções textuais a partir de pesquisas acadêmicas em artes cênicas. Revista da FUNDARTE, Montenegro, p.124-148, ano 19, no 39, julho/dezembro de 2019.

Disponível em: http://.seer.fundarte.rs.gov.br/index.php/RevistadaFundarte/index> 20 de dezembro de 2019. 


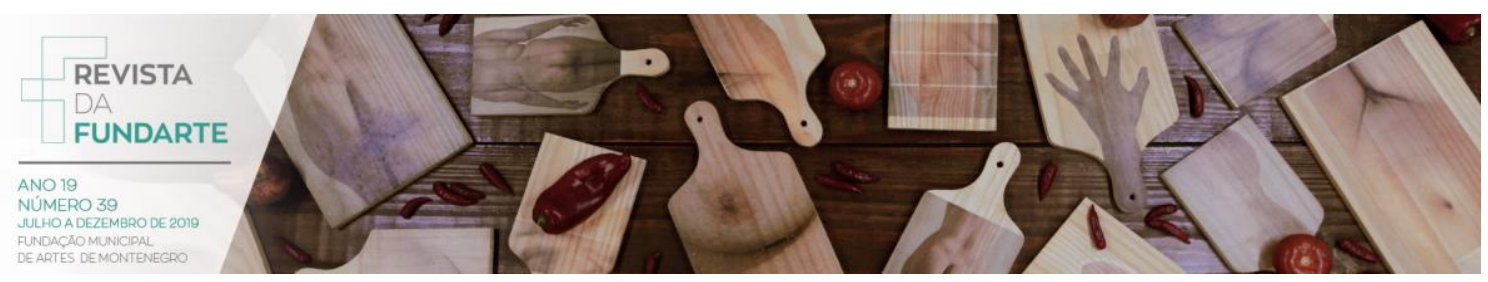

operar com as noções categorizadas por Dubatti, de maneira a exemplificá-las, apresentando figuras de esquemas e pirâmides de maneira pormenorizada. Questiono, porém, a abordagem da questão do "desejo" a partir da referência a Gilles Deleuze que, a meu ver, seria apropriada à reflexão de aspectos subjetivos, mas que, trazida na dissertação de forma tímida, pouco acrescenta às interessantes considerações de Demori. Ou seja, frente aos demais conceitos trazidos de forma definida e esmiuçada pela autora, vislumbro uma relação complementar no sentido de que um trabalho dessa natureza possa desdobrar-se no contexto da subjetividade.

Entendo que essa questão possa abarcar outros aspectos como o sentimento de pertencimento (anteriormente mencionado no trabalho), ou ainda, sobre o desejo de ressignificar costumes e tradições da cultura italiana, na qual a autora se insere.

Por fim, observei, entre as referências da dissertação - que trazem uma cuidada seleção de títulos que compõem la crème de la crème dos conceitos com os quais Juliana Demori opera - um estudo intitulado Produzir subjetividade, o que significa? Estudos e Pesquisa em Psicologia (MIRANDA e SOARES, 2009), que não é mencionado no decorrer do estudo. Seria este pequeno lapso um indício do desejo da pesquisadora de dar seguimento aos seus estudos sobre o Miseri Coloni na perspectiva da psicologia? A esta observação, acrescento a minha profunda alegria e gratidão pela leitura de um trabalho importante no campo dos estudos teatrais na perspectiva da Poética Comparada, segundo Jorge Dubatti, e fundamental à difusão do teatro gaúcho.

\section{NARRATIVAS DE ATRIZES NEGRAS SOBRE O TEATRO EM PORTO ALEGRE ${ }^{17}$}

A escolha da dissertação de Edilaine Ricardo Machado, atriz gaúcha conhecida artisticamente e carinhosamente por Dedy Ricardo, dá-se pelo fato do seu texto aproximar-se do tema de minha pesquisa de Doutorado, que envolve artistas

\footnotetext{
17 Escrito por lassanã Martins.
}

SANTOS, Vera Lúcia Bertoni (et.al). Cinco escritos para um mosaico: produções textuais a partir de pesquisas acadêmicas em artes cênicas. Revista da FUNDARTE, Montenegro, p.124-148, ano 19, no 39, julho/dezembro de 2019.

Disponível em: http://.seer.fundarte.rs.gov.br/index.php/RevistadaFundarte/index> 20 de dezembro de 2019. 


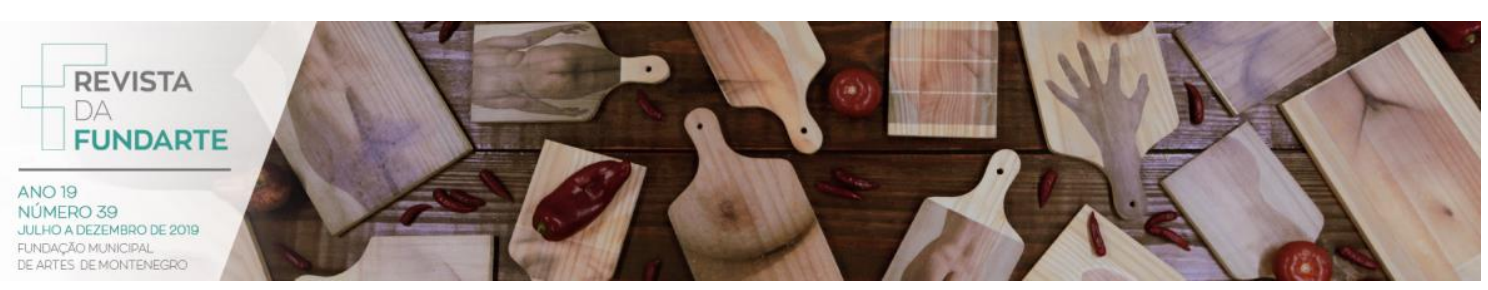

profissionais de Porto Alegre (RS); e pela oportunidade que o trabalho oferece de conhecer a trajetória artística de cinco atrizes negras, seja pela significativa trajetória das profissionais investigadas, seja por abordar a questão da negritude e da formação dessas atrizes no mercado de trabalho, que envolve a partilha não só da cena, mas de "processos de resistências" (MACHADO, 2017, p. 16) no cenário teatral da nossa cidade e, porque não dizer, do nosso país.

Machado inicia seu texto oferecendo uma escrita em formato de carta, dando indícios de suas escolhas como pesquisadora, de sua metodologia e das provocações teóricas, como ela mesma nomeia, e das inquietações das quais se originam a questão da sua pesquisa, tal seja, o modo de como mulheres atrizes negras constituem a si mesmas a partir da formação teatral e do exercício profissional em teatro.

Os procedimentos metodológicos são apresentados detalhadamente e em ordem cronológica: o ano de 2016 foi dedicado ao mapeamento das atrizes negras participantes da pesquisa (escolhidas a partir de indicações de profissionais ou de suas próprias referências), às entrevistas (gravadas em áudio) com as atrizes selecionadas e ao estudo do material produzido nas entrevistas. O critério de seleção das entrevistadas foi a época em que as atrizes iniciaram sua formação teatral e realizaram seus primeiros trabalhos artísticos, resultando na escolha de uma atriz referente à cada década, desde 1960 até 2010. O objetivo dessa organização por década era identificar o modo como as experiências das atrizes são atravessadas pelo contexto histórico. Desse modo, a primeira década, de 1960, é representada pela atriz Rosa Lima; os anos 1970, pela atriz Vera Lopes; a década de 1980, pela atriz Celina Alcântara; os anos 1990 têm como representante a própria autora, Dedy Ricardo; os 2000 são representados pela atriz Pâmela Amaro; e, por fim, a década de 2010, tem como representante a atriz Manuela Miranda.

A apresentação das atrizes entrevistadas dá-se no primeiro capítulo da Dissertação, com exceção da "atriz representante da década de 90" (MACHADO, 2017. p. 16), cuja apresentação é feita logo na introdução do trabalho, mediante uma narrativa

SANTOS, Vera Lúcia Bertoni (et.al). Cinco escritos para um mosaico: produções textuais a partir de pesquisas acadêmicas em artes cênicas. Revista da FUNDARTE, Montenegro, p.124-148, ano 19, no 39, julho/dezembro de 2019.

Disponível em: http://.seer.fundarte.rs.gov.br/index.php/RevistadaFundarte/index> 20 de dezembro de 2019. 


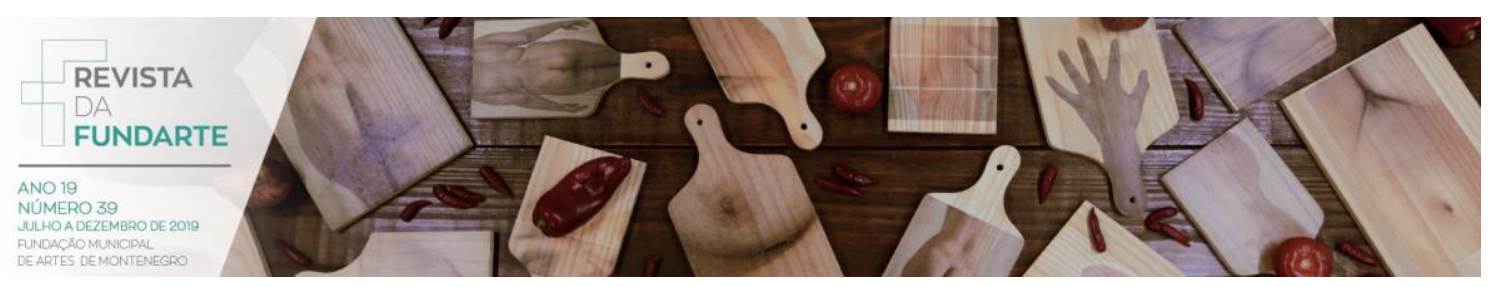

da trajetória da autora no teatro e dos caminhos que a levaram a identificar possíveis semelhanças entre ela e as demais atrizes negras que participam do seu estudo.

O conceito de escrita de si, de Michel Foucault (2010), perpassa a escrita, abarcando as subjetividades, assim como o discurso de embranquecimento e colorismo como transformação, de constituição de si e formação teatral, que dizem respeito a um trabalho que remete a "si" como aspecto significativo da transformação teatral (formação de si). Com o intuito de dar a conhecer as entrevistadas, a pesquisadora utiliza de frases das atrizes, compondo poeticamente os títulos dos capítulos e subcapítulos. Assim, o trabalho é pontuado por ideias que permeiam o feminismo negro, a partir de autoras como Bell Hooks (2004), Aline Djokic (2016), Angela Davis (2013), Ochy Curiel (2005) e Conceição Evaristo (2005).

Já o segundo capítulo dialoga com as questões do teatro negro, dos modos de como a dramaturgia é escrita na história do Brasil, seus principais atores e atrizes negras, e até a própria disputa de quem foram os primeiros a tratar a questão da negritude no nosso teatro, ou seja, evidencia um contexto de uma história que pouco conhecemos. E finaliza com considerações referentes à autotransformação, a partir das narrativas das atrizes sobre seus contextos e experiências teatrais; e com análises das estratégias por meio das quais as atrizes escapam do lugar de subalternidade na cena, tornando-se protagonistas de seu próprio fazer artístico.

[...] na labuta cotidiana, no trânsito entre os palcos, as salas de ensaio e as rodas do teatro de rua, atrizes negras acessam em si mesmas a negrura e aventuram-se a desbravá-la. Ao estabelecerem uma relação ética com esse aspecto particular de si, essas mulheres dão voz à experiência de seus corpos negros diante das plateias, que bebem de suas histórias cantadas e dançadas, histórias que antes viviam sob o jugo da mordaça. (MACHADO 2017, p. 91).

A dissertação de Machado reflete sobre um tipo de conhecimento peculiar, que se dá pela trajetória de um corpo imbuído de profundidade em relação às questões que o cercam: um corpo que sabe o que é ser mulher, atriz, negra, e que reconhece esses

SANTOS, Vera Lúcia Bertoni (et.al). Cinco escritos para um mosaico: produções textuais a partir de pesquisas acadêmicas em artes cênicas. Revista da FUNDARTE, Montenegro, p.124-148, ano 19, ㄲo 39, julho/dezembro de 2019.

Disponível em: http://.seer.fundarte.rs.gov.br/index.php/RevistadaFundarte/index $>20$ de dezembro de 2019. 


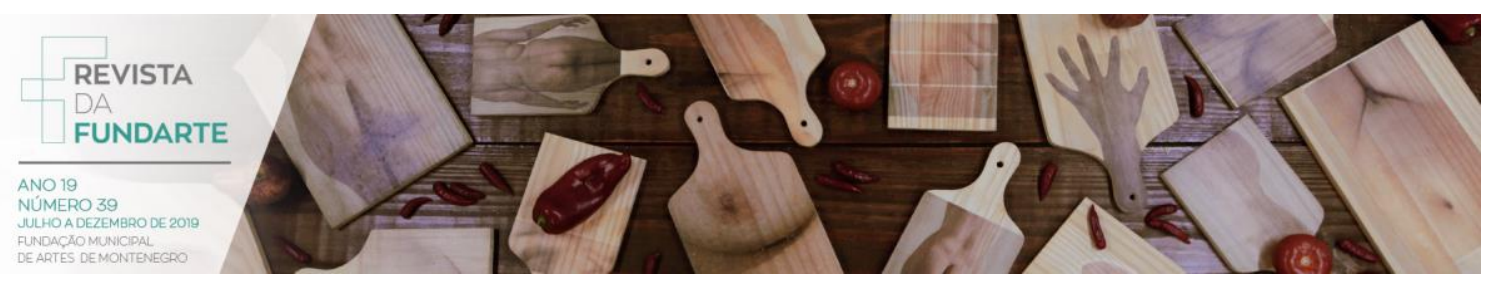

aspectos na trajetória e nos corpos de outras. Ainda que a entrevistada Celina Alcântara surpreenda a pesquisadora, por manifestar no seu discurso uma compreensão diferenciada, distanciando-se do discurso das demais.

Contudo, amigas e amigos, a entrevista com Celina não apenas me surpreende, como também desestabiliza o rumo da pesquisa, que, até então, vinha pautada pelo silêncio que, de alguma forma, se impunha diante das mulheres negras, por intermédio dos processos de embranquecimento, da herança da violência imposta pela escravidão, ou, ainda, pela ausência de reconhecimento nos meios sociais, conforme relataram as atrizes que aqui já foram citadas. Ainda que Celina tenha se deparado prematuramente com a responsabilidade da manutenção de uma casa e do cuidado dos irmãos, funções vistas pela sociedade como subalternas e de caráter secundário, e que essas funções lhe tenham sido atribuídas em virtude da sua condição de classe, gênero e cor, ela não reconhece, em suas experiências primeiras, ligadas à infância e à adolescência, a ação do silenciamento sobre si mesma. (MACHADO, 2017, p.38).

O anseio por aprofundar o tema leva-me a apontar algumas lacunas no texto (decorrentes das próprias limitações de um estudo dessa natureza), ou curiosidades que ele desperta, especialmente em algumas passagens que reúnem falas das atrizes entrevistadas, nas quais a autora, na busca por identificar aspectos em comum das trajetórias em foco, parece abrir mão da linearidade das narrativas. As vozes dessas mulheres negras, atrizes da cena porto-alegrense ouvidas por Machado carregam consigo histórias de artistas, de grupos, espetáculos e movimentos constitutivos da história do nosso teatro, que merecem ser documentadas de forma mais detalhada.

Se, por um lado, o estudo de Machado aponta um campo em aberto, a ser explorado em pesquisas futuras, na medida em que possibilita, através de narrativas de atrizes negras que desbravaram e desbravam a cena de Porto Alegre, conhecemos uma parte pouco difundida da história do nosso teatro; por outro, instaura outros modos de olhar para a trajetória de artistas mulheres. Nesse sentido, agradeço à colega Dedy, por "emprestar o olhar" - como ela apropriadamente menciona no texto - para este aspecto.

SANTOS, Vera Lúcia Bertoni (et.al). Cinco escritos para um mosaico: produções textuais a partir de pesquisas acadêmicas em artes cênicas. Revista da FUNDARTE, Montenegro, p.124-148, ano 19, no 39, julho/dezembro de 2019.

Disponível em: http://.seer.fundarte.rs.gov.br/index.php/RevistadaFundarte/index> 20 de dezembro de 2019. 


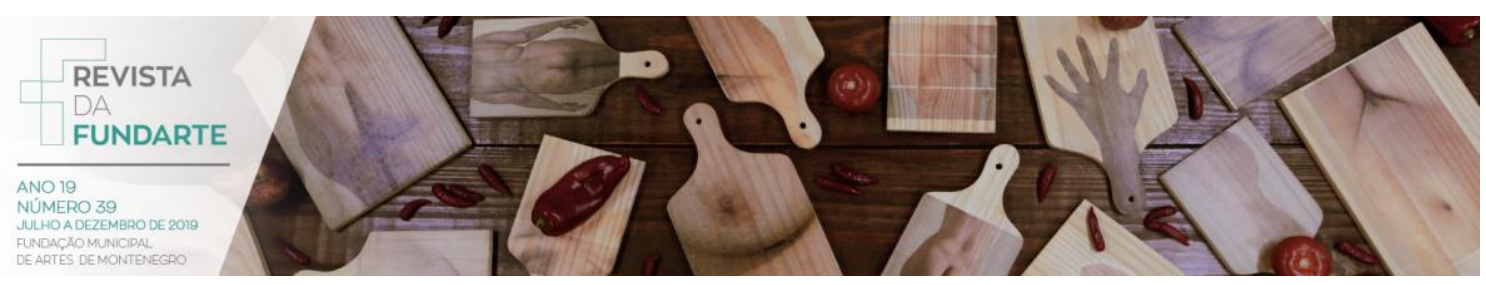

Considerando o meu interesse de pesquisadora pela trajetória de artistas mulheres inseridas no campo de trabalho da cena teatral local, numa perspectiva diversa, identifico, a partir do trabalho de Machado, a questão da negritude. De acordo com Angela Davis, para que o feminismo avance, é preciso olhar para a luta das mulheres negras. Nesse sentido, pretendo estar atenta ao que diz respeito ao teatro e a história das mais diversas mulheres e da vida que elas carregam consigo.

\section{Referências:}

DEMORI, Juliana Canali. Poéticas singulares: um estudo sobre a territorialidade na produção artística do grupo de teatro Miseri Coloni, de Caxias do Sul/RS. Dissertação (Mestrado em Artes Cênicas). Universidade Federal do Rio Grande do Sul. Porto Alegre, 2016.

MACHADO, Edilaine Ricardo. Negritude e formação teatral: vozes mulheres na cena de Porto Alegre/Brasil. Dissertação (Mestrado em Artes Cênicas). Universidade Federal do Rio Grande do Sul. Porto Alegre, 2017.

ROSSINI, Élcio. Tarefas: uma estratégia para criação de performances. Tese (Doutorado em Artes Visuais). Universidade Federal do Rio Grande do Sul. Porto Alegre, 2011.

SILVA, Carmi Ferreira da. Por uma história da Dança: reflexões sobre as práticas historiográficas para a Dança, no Brasil Contemporâneo. Dissertação (Mestrado em Dança). Universidade Federal da Bahia. Salvador, 2012.

ZALTRON, Michele Almeida. O trabalho do ator sobre si mesmo segundo o "sistema" de K. Stanislávski (Tese). Programa de Pós-graduação em Artes Cênicas, Universidade Federal do Rio de Janeiro. Rio de Janeiro, 2016.

SANTOS, Vera Lúcia Bertoni (et.al). Cinco escritos para um mosaico: produções textuais a partir de pesquisas acadêmicas em artes cênicas. Revista da FUNDARTE, Montenegro, p.124-148, ano 19, nº 39, julho/dezembro de 2019.

Disponível em: http://.seer.fundarte.rs.gov.br/index.php/RevistadaFundarte/index> 20 de dezembro de 2019. 